\title{
Conformational Changes of $\alpha_{\mathrm{s}}$-Casein by Heating
}

\author{
Tomotada ONo,* Katsuhide YUTANI and Satoshi OdaGIRI** \\ The Institute for Protein Research, Osaka University, Suita \\ **Department of Agricultural Chemistry, Iwate University, Morioka \\ Received June 19, 1972
}

\begin{abstract}
Conformational changes of $a_{\mathrm{s}}$-casein by heating were investigated by measuring ultraviolet difference spectra. The ultraviolet difference spectra at elevated temperature against $5.5^{\circ} \mathrm{C}$ were measured in various ionic strengths and $\mathrm{pHs}$. Thermal effects of the difference spectra were cancelled by comparing with the spectra of model compounds such as lysozyme and ribonuclease, and the blue shift of $a_{5}$-casein spectra was observed at above $30^{\circ} \mathrm{C}$ in these all experimental conditions. This shift was considered to mean unfolding of the $a_{s}$-casein molecule. The aggregation of $a_{\mathrm{s}}$-casein was observed above ionic strength of 0.4 by heating. These heat-induced changes were reversible until the aggregation was observed.
\end{abstract}

Pasteurizing, sterilizing and evaporating processes are essential for milk processing and storage. These heat processes are considered to cause soft curd and cooked flavor problems, forewarming effect and etc. ${ }^{13}$ There are a number of investigations ${ }^{2,3)}$ on the factors influencing heat stability of milk. But, the study on conformational changes of $a_{\mathrm{s}}$-casein by heating has not been carried out enough. It is owing to the following reasons. $\mathrm{K}$-Casein and $\beta$-lactoglobulin contain the residues involving $-\mathrm{SH}$ and $\mathrm{S}-\mathrm{S}$, but $a_{\mathrm{s}}$-casein does not contain these residues and not aggregate even if it is heated at $100^{\circ} \mathrm{C}$. Since $a_{\mathrm{s}}$-casein contained little $\alpha$-helix and $\beta$ structure but contained a random structure, ${ }^{4}$ it is difficult to detect a conformational change of $a_{\mathrm{s}}$-casein. However, Kresheck et al. ${ }^{5)}$ reported that marked aggregation of $a_{\mathrm{s}}$-casein was observed by heating at $70^{\circ} \mathrm{C}$. Leslie et $a l^{\left.{ }^{0}\right)}$ recently showed that the increase of temperature or the addition of urea lead to expose the non-polar residues of $a_{\mathrm{s}}$-casein by means of the NMR measurement.

In this paper, the conformational changes of $a_{\mathrm{s}}$-casein by heating are repored as having been investigated by using ultraviolet difference spectra measurements which can detect a small conformational change.

* Present address: Department of Agricultural Chemistry, Iwate University, Morioka

\section{MATERIALS AND METHODS}

1. $a_{\mathrm{s}}$-Casein. $a_{\mathrm{s}}$-Casein was prepared from Holstein cows' milk by the method of Zittle and Custer, ${ }^{7}$ ) and the removal of impurities by ethanol treatment was repeated twice. The solution of $a_{\mathrm{s}}$-casein was filtered through ${ }^{\text {a) }} 0.45 \mu$ Milipore filter, dialyzed against $30 \mathrm{~mm}$ EDTA solution ( $\mathrm{pH} \mathrm{7.0)}$ and then against deionized water at $4^{\circ} \mathrm{C}$, and followed lyophilization. $a_{\mathrm{s}}$-Casein prepared was homogeneous in the disc gel electrophoresis. $a_{\mathrm{s}}$-Casein solution used for measurements was prepared by mixing about $1 \%$ $a_{\mathrm{s}}$-casein stock solution, $0.2 \mathrm{M}$ phosphate buffer of pH 6.9 and $1 \mathrm{M} \mathrm{NaCl}$ solution: being adjusted to 0.13 or $0.4 \% a_{\mathrm{s}}$-casein in $0.02 \mathrm{M}$ phosphate buffer of $\mathrm{pH} 6.9$ and ionic strength 0.094 (standard buffer). These solutions were used for measurements after being allowed to stand for $1 \mathrm{hr}$, and the concentration of $a_{\mathrm{s}}$-casein was determined spectrophotometrically: $a_{\mathrm{s}}$-casein $E_{1 \mathrm{~m}}^{1 \% \%}=10.0$ at $280 \mathrm{~nm}^{81}$

2. Ribonuclease, lysozyme and other chemicals. Six times crystallized lysozyme from hen egg white (Seikagaku Kogyo Co.) and five times crystallized ribonuclease from bovine pancreas (Sigma Chemical Co.) were used without further purification. The concentration of these protein samples was determined spectrophotometrically: lysozyme $E_{1 \mathrm{~cm}}^{1 \%}=26.9$ at $280 \mathrm{~nm}^{91}$ and ribonuclease $\varepsilon=9800$ at $277.5 \mathrm{~nm}^{10}$ $(13,683)$. $^{111}$

Guanidine hydrochloride was recrystallized from methanol, and urea from $70 \%$ acqueous ethanol. Other chemicals were of guaranteed reagent grade and used without further purification.

3. Ultraviolet difference spectra. UItraviolet (UV) difference spectra were measured with a Jasco spectropolarimeter model J-10 which was improved to meas- 
ure at full scale 0.1 in optical density, and the full scale of the instrument was set to 0.2 optical density. A reference cell and a sample cell were maintained at different temperature by employing separate cell holders. $\quad a_{\mathrm{s}}$-casein solution was prepared to $0.13 \%$ in concentration and the solution of lysozyme or ribonuclease was prepared to $E_{1 \mathrm{~cm}}=1.5 \pm 0.2$ at $280 \mathrm{~nm}$ in $0.1 \mathrm{M} \mathrm{NaCl}$. $\varepsilon$ of $a_{\mathrm{s}}$-casein was calculated from MW 27,000.12!

4. Optical rotation and circular dichroism measurements. Optical rotation (OR) measurements were made at $365 \mathrm{~nm}$ by using a Perkin Elmer-141-polarimeter with a $10 \mathrm{~cm}$ standard cell. The concentration of $a_{\mathrm{s}}$-casein was $0.4 \%$ and the reduced mean residue rotations, [m'], were calculated from the mean residue molecular weight 122.131

Circular dichroism (CD) measurements were carried out by using a Jasco spectropolarimeter model J-10 with a cell holder which was maintained at definite temperature.

5. Maintenance of temperature. The temperature was held within $\pm 0.1^{\circ} \mathrm{C}$ by connecting cell holders with a Haake KT62 (below $10^{\circ} \mathrm{C}$ ) and a Colora ultrathermostat $\mathrm{NB}-32,741$ (above $10^{\circ} \mathrm{C}$ ). The temperature in each cell was measured by a Takara thermistor.

\section{RESULTS}

\section{Measurements of $U V$ difference spectra}

$U V$ difference spectra of $a_{\mathrm{s}}$-casein. UV difference spectra as shown in Fig. 1 indicate the effects of temperature on $\alpha_{s}$-casein in the standard buffer. The temperature of the reference cell was maintained at $5.5^{\circ} \mathrm{C}$, and

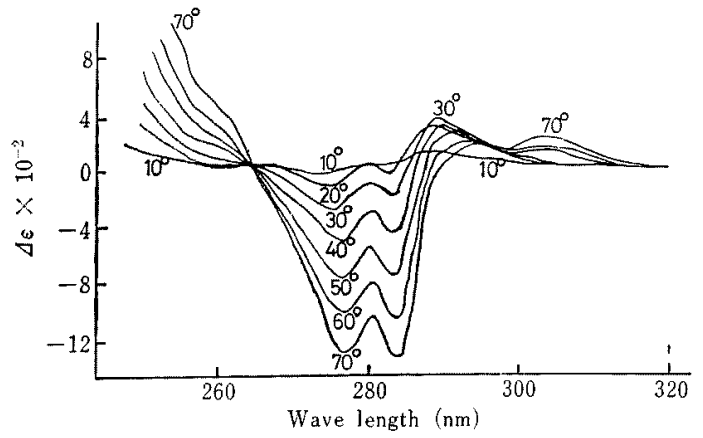

FIG. 1. Ultraviolet Difference Spectra of $a_{\mathrm{s}}$-Casein as a Function of Temperature.

The reference cell was at $5.5^{\circ} \mathrm{C}$ and the Sample's temperature gradually raised. Conditions: protein concentration, $0.12 \%$ in the standard buffer $(0.02 \mathrm{M}$ phosphate buffer pH 7.0, ionic strength 0.094). that of the sample cell was gradually raised. The difference spectra of $a_{\mathrm{s}}$-casein did not change with time at each temperature measured. Therefore, difference spectra were measured within 5 to $30 \mathrm{~min}$ after the cell had reached a definite temperature. These spectra had an isobestic point at $263 \mathrm{~nm}$, and as the temperature of the sample cell was raised, the $\Delta \varepsilon$ values became progressively greater in all wave lengths measured except for the isobestic point and $290 \mathrm{~nm}$ region. The $\Delta \varepsilon$ values at $290 \mathrm{~nm}$ became smaller at the higher temperature than $30^{\circ} \mathrm{C}$.

Figure 2 shows the effects of temperature on the completely unfolded $a_{\mathrm{s}}$-casein in the standard buffer containing $5 \mathrm{M}$ guanidine hydrochloride. These difference spectra have two isobestic points at 255 and $284 \mathrm{~nm}$, and all $\Delta \varepsilon$ values become greater in proportion to temperature. The effects of temperature on the spectra of acetyl tyrosine ethyl-ester (Fig. 3) and acetyl tryptophan ethylester are similar to these on the spectra of the completely unfolded $a_{\mathrm{s}}$-casein, and both spectra have 2 or 3 isobestic points. It is considered that these phenomena are caused by the so-called thermal effects, not being accompanied by the conformational changes of solute. The effects can be shown by that the $\Delta \varepsilon$ values become

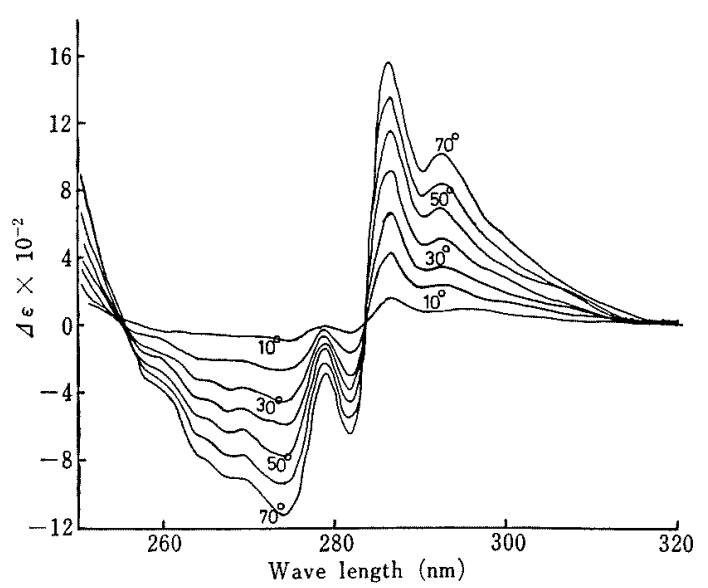

FIG. 2. Temperature Difference Spectra of Ultraviolet Absorption of $a_{\mathrm{s}}$-Casein in the Standard Buffer Containing $5 \mathrm{~m}$ Guanidine Hydrochloride.

The temperature of the reference cell was maintained at $5.5^{\circ} \mathrm{C}$ and the concentration of protein was $0.136 \%$. 


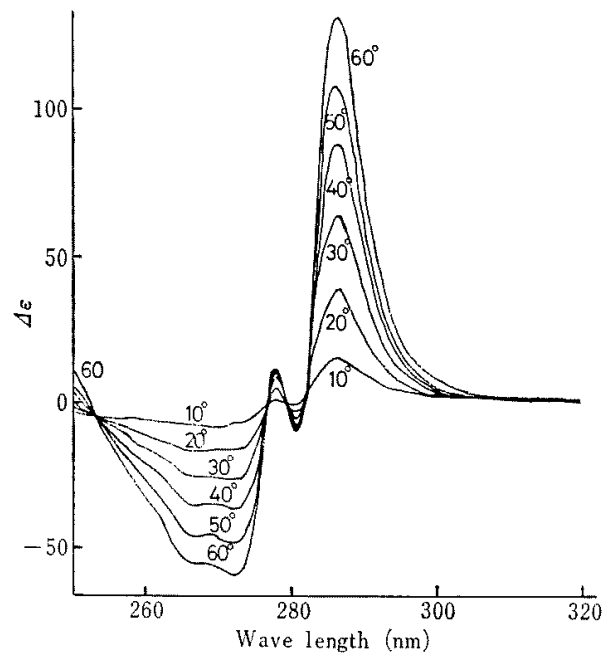

FIG. 3. Temperature Difference Spectra of Acetyl Tyrosin Ethylester in the Standard Buffer.

The temperature of the reference cell was maintained at $5.5^{\circ} \mathrm{C}$ and the concentration of acetyl tyrosin ethylester was $0.025 \%$.

greater in proportion to temperature and that the spectra have isobestic points. Considering this fact, it seemed that the result of Fig. 2 shows also thermal effects and that Fig. 1 shows the spectra which were caused by both conformational change and the thermal effects. As to $a_{\mathrm{s}}$-casein and the completely unfolded $a_{\mathrm{s}}$-casein, the observed effects of temperature were perfectly reversible.

A comparison of $a_{\mathrm{s}}$-castin with lysozyme and ribonuclease. The ribonuclease was used as a model compound which undergoes conformational change by heating, and the lysozyme as one which does not undergo conformational change by heating. ${ }^{16)}$ The difference spectra of these model compounds were measured with the same procedure as $a_{\mathrm{s}}$-casein (Figs. 1 and 2). The temperature of the sample cell was gradually raised. Figure 4 shows the effect of temperature on lysozyme, and Fig. 5 shows that on ribonuclease. The spectra of lysozyme have two isobestic points and the $\Delta \varepsilon$ values become greater in proportion to temperature: the effects may be caused by the thermal effect only. On the spectra of ribonuclease the $\Delta \varepsilon$ values become greater in

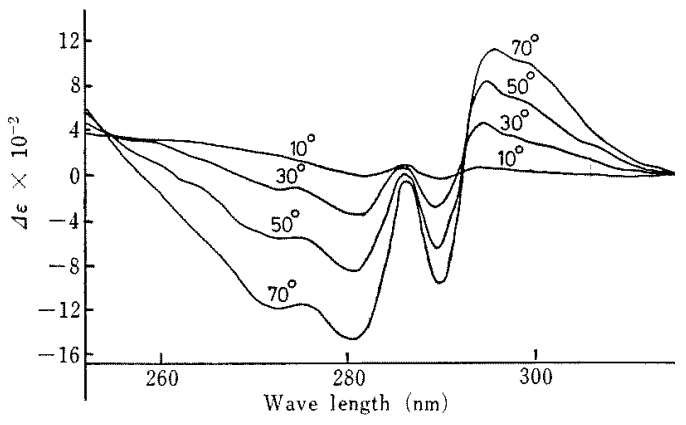

FIG. 4. Temperature Difference Spectra of Lysozyme in $0.1 \mathrm{M} \mathrm{NaCl}$ Solution of $\mathrm{pH} 6.0$.

The temperature of the reference cell was maintained at $5.5^{\circ} \mathrm{C}$ and the concentration of the protein was $0.043 \%$.

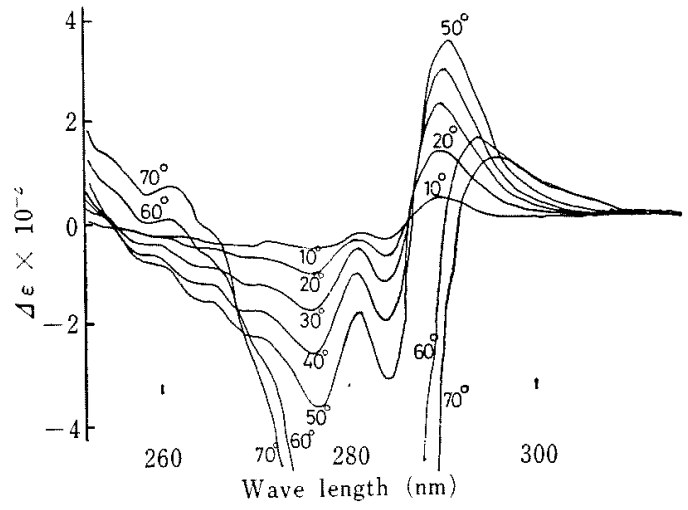

FIG. 5. Temperature Difference Spectra of Ribonuclease in $0.1 \mathrm{~m} \mathrm{NaCl}$ Solution of $\mathrm{pH} 4.6$.

The temperature of the reference cell was maintained at $5.5^{\circ} \mathrm{C}$ and the concentration of the protein was $0.19 \%$.

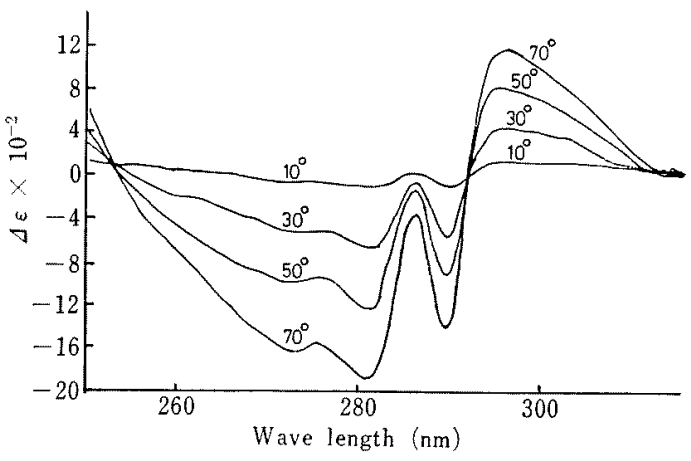

FIG. 6. Temperature Difference Spectra of Lysozyme in $0.1 \mathrm{M} \mathrm{NaCl}$ Solution of pH 5.2 Containing 5 m Guanidine Hydrochloride.

The temperature of the reference cell was maintained at $5.5^{\circ} \mathrm{C}$ and the concentration of the protein was $0.043 \%$. 


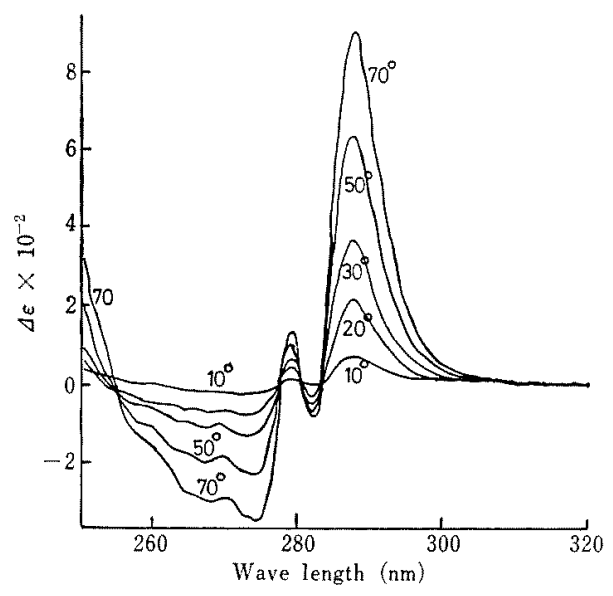

FIG. 7. Temperature Difference Spectra of Ribonuclease in $0.1 \mathrm{M} \mathrm{NaCl}$ Solution of $\mathrm{pH} 4.6$ Containing 5 м Guanidine Hydrochloride.

The temperature of the reference cell was maintained at $5.5^{\circ} \mathrm{C}$ and the concentration of the protein was $0.19 \%$.

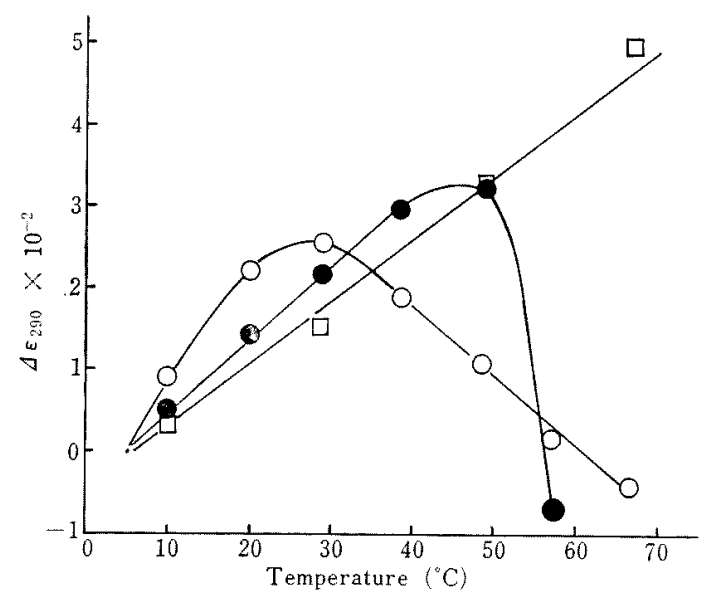

Fig, 8. Change of $d_{s}$ at $290 \mathrm{~nm}$ of $a_{\mathrm{s}}$-Casein, Ribonuclease, and Lysozyme as a Function of Temperature.

The temperature of the reference cells was maintained at $5.5^{\circ} \mathrm{C} .0$ : $a_{\mathrm{s}}$-casein, protein concentration of $0.126 \%$, standard buffer. : ribonuclease, protein concentration of $0.19 \%, 0.1 \mathrm{M} \mathrm{NaCl}$ solution of pH 4.6. $\square$ : lysozyme, protein concentration of $0.04 \%$, $0.1 \mathrm{M} \mathrm{NaCl}$ solution of $\mathrm{pH} 6.0$.

proportion to temperature up to $40 \mathrm{C}$, and then decrease rapidly above $50^{\circ} \mathrm{C}$. This shows a blue shift of absorption spectra, to be caused by the heat-induced change of conformation above $50^{\circ} \mathrm{C}$. The blue shift of absorption spectra is usually caused by exposing chromophor residues out of molecule. Difference spectra of lysozyme and ribonuclease in $0.1 \mathrm{M} \mathrm{NaCl}$ solution containing $5 \mathrm{M}$ guanidine hydrochloride are shown in Fig. 6 and Fig. 7. These spectra have isobestic points and the $\Delta \varepsilon$ values become greater in proportion to temperature, showing thermal effects only. Figure 8 shows $\Delta \varepsilon$ values at $290 \mathrm{~nm}$ of lysozyme, ribonuclease, and $a_{\mathrm{s}}$-casein as a function of temperature. These results show clearly that lysozyme undergoes the thermal effects only, and that ribonuclease gives rise rapidly to the blue shift by the conformational change above $50^{\circ} \mathrm{C}$. Therefore, it is considered that comparing $a_{\mathrm{s}}$-casein with lysozyme and ribonuclease, the blue shift of $a_{5}$-casein spectra occurred by heating above $30^{\circ} \mathrm{C}$. And the blue shift may have been caused by the dissociation of $a_{\mathrm{s}}$-casein and/or the unfolding of a molecule of $a_{\mathrm{s}}$-casein, for the exposing of chromophor residues out of molecule can be caused by these two reasons.

The influences of ionic strength. The temperature difference spectra of $\alpha_{\mathrm{s}}$-casein were measured at various ionic strengths. Figure 9 shows the temperature difference spectra of $a_{\mathrm{s}}$-casein in the case of ionic strength of 0.84 . These spectra were similar to those shown in Fig. 1. The rise of $320 \mathrm{~nm}$ regions, however, occurred at $50^{\circ} \mathrm{C}$ and turbidity was observed. The turbidity was increased with time at the temperature where the turbidity arised. The

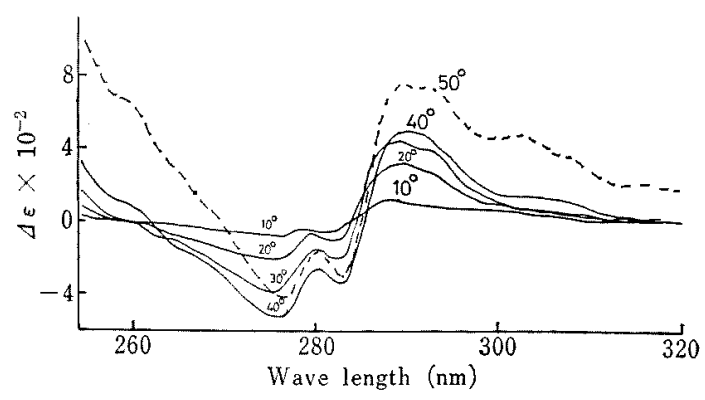

FIG. 9. Temperature Difference Spectra of $\alpha_{\mathrm{s}}$-Casein at Ionic Strength of 0.84 in $0.02 \mathrm{M}$ Phosphate Buffer of $\mathrm{pH} 7.0$.

The temperature of the reference cell was maintained at $5.5^{\circ} \mathrm{C}$ and the concentration of the protein was $0.136 \%$. 


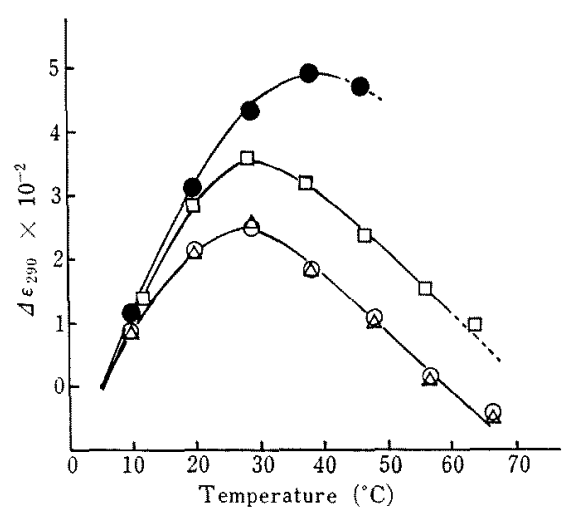

FIG. 10. Change of $\Delta_{\varepsilon}$ at $290 \mathrm{~nm}$ of $\alpha_{\S}$-Casein in Various Ionic Strengths as a Function of Temperature. The temperature of the reference cells was maintained at $5.5^{\circ} \mathrm{C}$ and the concentration of the protein was $0.136 \%$. Signs of $O, \triangle, \square$ and $\bullet$ show ionic strength of $0.094,0.244,0.444$ and 0.844 respectively, in $0.02 \mathrm{M}$. phosphate buffer of $\mathrm{pH} \mathrm{7.0.} \mathrm{Dotted} \mathrm{lines} \mathrm{show} \mathrm{the}$ region at which the turbidity was observed.

rate of formation of aggregate was increased with an increase in temperature. The turbidity formed once, was not extinguished by decrease in temperature. The extent of the increase of $\Delta \varepsilon$ values at $290 \mathrm{~nm}$ reduced at $40^{\circ} \mathrm{C}$ in spite of forming the aggregate. Then $d \varepsilon$ of UV difference spectra at $290 \mathrm{~nm}$ in the buffer of various concentrations of $\mathrm{NaCl}$ solution were plotted against temperature in Fig. 10. The decrease of $\Delta \varepsilon$ values occurred between $30^{\circ} \mathrm{C}$ and $40^{\circ} \mathrm{C}$ in all ionic strengths prepared. This shows that the blue shift occurred in all ionic strengths. The higher in the ionic strength, the greater in the $A \varepsilon$ values against temperature. The increase of $\Delta \varepsilon$ values probably means the red shift of absorption spectra, which is caused by folding of chromophor residues inside molecule.

Then the UV difference spectra of $a_{\mathrm{s}}$-casein in buffers of various ionic strengths against $a_{\mathrm{s}}$-casein in the standard buffer were measured, and the temperature of both cells was raised simultaneously. The UV difference spectra in the case of ionic strength of 0.84 are shown in Fig. 11. The ionic strength higher than the one in the standard buffer caused the red shift of $a_{\mathrm{s}}$-casein spectra. And the red shift was greater with increase in temperature, and the $320 \mathrm{~nm}$ region of the spectra came to rise

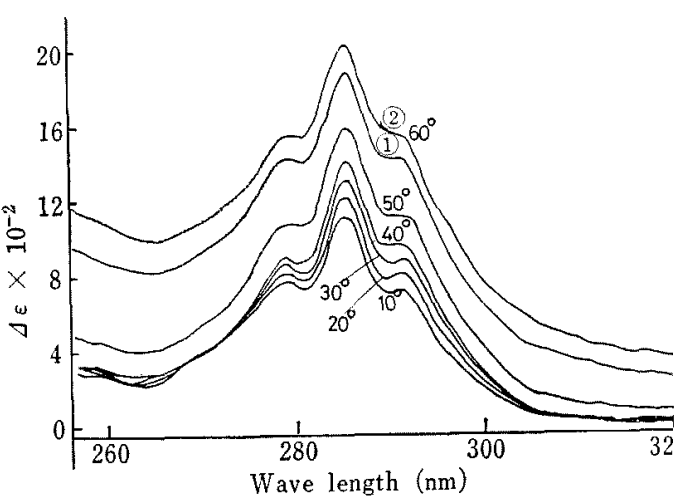

FIG. 11. Effect of Temperature on the Difference Spectra of $a_{\mathrm{s}}$-Casein at Ionic Strength of 0.84 against Ionic Strength of 0.094 .

The temperature of the both cells was raised simultaneously. The concentration of the protein was $0.136 \%$. The curve (2) at $60^{\circ} \mathrm{C}$ was obtained 10 min after the curve (1).

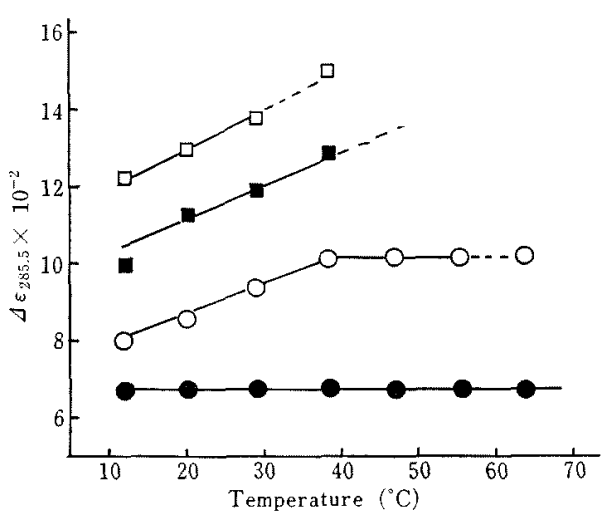

FIG. 12. Effect of Temperature on $\Delta \varepsilon$ at $285.5 \mathrm{~nm}$ of $a_{\mathrm{s}}$-Casein in Various Ionic Strengths against the Standard Buffer.

The concentration of the protein was $0.136 \%$. The ionic strength of the standard buffer was 0.094 , and those of sign 0,0 , and $\square$ were $0.24,0.44,0.84$ and 1.24 , respectively.

from $50^{\circ} \mathrm{C}$; turbidity was formed. The $\Delta \varepsilon$ values at $285.5 \mathrm{~nm}$ of $a_{\mathrm{s}}$-casein in buffers of various ionic strengths against those in the standard buffer were plotted against temperature as shown in Fig. 12. As the ionic strength became higher, the $\Delta s$ values were greater; the red shift occurred, and the red shift was greater with increase in temperature except below ionic strength 0.24 . The dotted lines show the formation of aggregate. As the red shift became greater by increasing ionic 
strength, the aggregate began to form at lower temperature. Since the red shift of absorption spectra is usually caused by the association of molecules, these results would mean that $a_{\mathrm{s}}$-casein associates one another with increase in ionic strength and the association is accelerated with temperature, and finally an aggregate is formed.

The influences of $p H$ and $a_{\mathrm{s}}$-casein concentration. The following experiments were carried out to make clear the influences of $\mathrm{pH}$ and $\alpha_{\mathrm{s}}$-casein concentration. The difference spectra were measured of $a_{\mathrm{s}}$-casein solution adjusted to $\mathrm{pH} \mathrm{6.2,6.9} \mathrm{and} \mathrm{7.8.} \mathrm{The}$ reference cell was maintained at $5.5^{\circ} \mathrm{C}$, and the temperature of sample cell was raised. The $\mathrm{pH}$ change from $3^{\circ} \mathrm{C}$ to $70^{\circ} \mathrm{C}$ in each solution

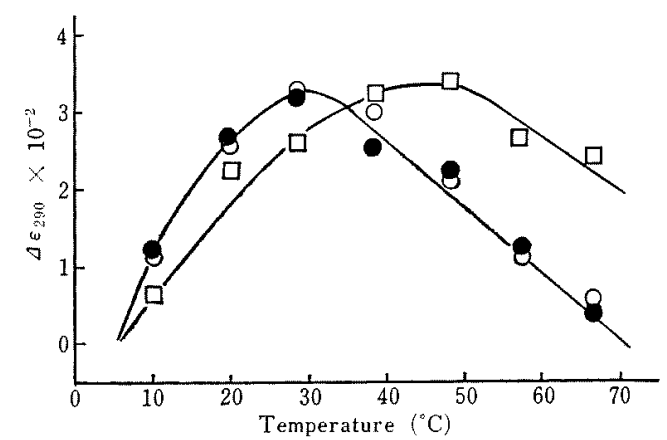

FIG. 13. Effect of $\mathrm{pH}$ on $d \varepsilon$ at $290 \mathrm{~nm}$ of $a_{8}$-Casein as a Function of Temperature.

The reference cell was maintained at $5.5^{\circ} \mathrm{C}$ and the concentration of the protein was $0.136 \%$. The solution were at pH $6.2(\bullet), \mathrm{pH} 6.9(0)$, and $\mathrm{pH} 7.8(\square)$.

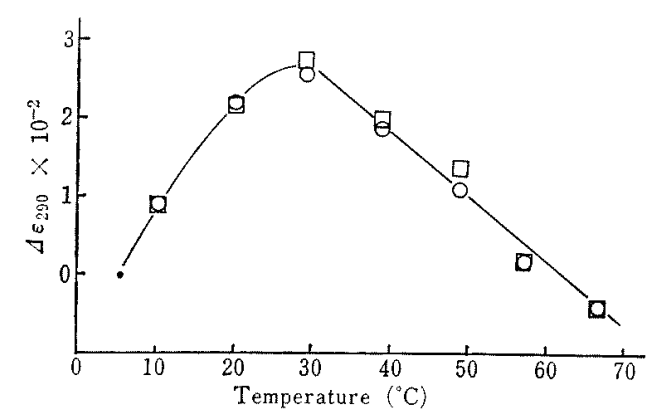

FIG. 14. Effect of the Concentration of $a_{\mathrm{S}}$-Casein on $\Delta \varepsilon$ at $290 \mathrm{~nm}$ as a Function of Temperature.

The reference cell was maintained at $5.5^{\circ} \mathrm{C}$ and the concentrations of the protein were $0.12 \%(0)$ and $0.27 \%(\square)$ was only $0.1 \mathrm{pH}$. Results are shown in Fig. 13. The $\Delta \varepsilon$ values at $\mathrm{pH} 6.2$ were similar to those at $\mathrm{pH} 6.9$, but the heat-induced change was shifted to higher temperature at $\mathrm{pH} 7.8$.

The temperature difference spectra were measured in the concentrations of 0.12 and $0.27 \%$. The values at $290 \mathrm{~nm}$ are shown in Fig. 14 , indicating similar $\Delta \varepsilon$ values in both concentrations.

\section{Measurements of circular dichroism and optical rotation}

In the standard buffer, the CD spectra of $a_{\mathrm{s}}$-casein at 5,30 and $70^{\circ} \mathrm{C}$ showed similar

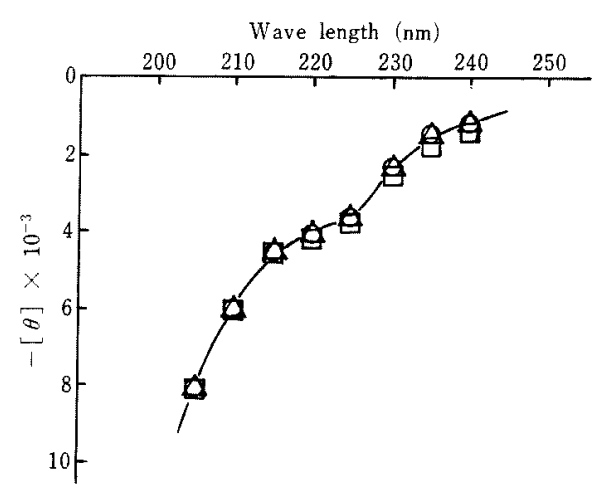

FrG. 15. Effect of Temperature on the Circular Dichroism of $a_{\mathrm{s}}$-Casein in the Standard Buffer.

The temperatures of the solution were $5^{\circ} \mathrm{C}(\mathrm{O}), 25^{\circ} \mathrm{C}$ $(\triangle)$, and $67^{\circ} \mathrm{C}(\square)$; and the concentration of the protein was $0.297 \%$.

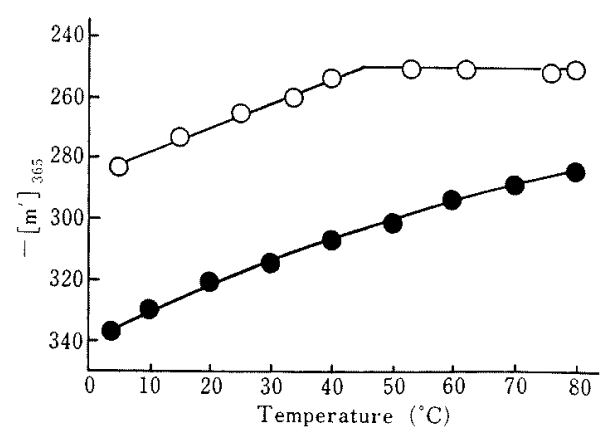

FIG. 16. Effect of Temperature on the Optical Rotation of $a_{\mathrm{s}}$-Casein.

$0: 0.56 \%$ in the standard buffer, $0: 0.33 \%$ in the standard buffer containing $5 \mathrm{M}$ guanidine hydrochloride. 
patterns in the $210 \sim 250 \mathrm{~nm}$ region as shown in Fig. 15. Then, temperature changes of the reduced mean residue rotation of $a_{\mathrm{s}}$-casein at $365 \mathrm{~nm}$ were measured and shown in Fig. 16. In the standard buffer the monotonous decrease in levorotation was observed from $5^{\circ} \mathrm{C}$ to $45^{\circ} \mathrm{C}$, and depressed at $45^{\circ} \mathrm{C}$. In the presence of $5 \mathrm{M}$ guanidine hydrochloride the monotonous decrease in levorotation was observed from $5^{\circ} \mathrm{C}$ to $80^{\circ} \mathrm{C}$. As to the decrease in levorotation accompanying the increase of temperature, Aune et al ${ }^{17}$ explained that these properties depend on environmental factors according to the rule of Kauzman and Eyring, ${ }^{18)}$ and levorotation is increased when the structure is disrupted. In Fig. 16, therefore, it is considered that the prevention of decrease in the levorotation of $\alpha_{\mathrm{s}}$-casein resulted from the compensation of thermal effects and the disruption of structure, and that the heat-induced change of $a_{\mathrm{s}}$-casein occurred at $45^{\circ} \mathrm{C}$.

\section{DISCUSSION}

\section{On thermal effects}

When one attempts to investigate heatinduced change in the conformation of protein, the following effects will contribute to an absorption spectral change with temperature: $:^{15}$ (1) change in the real optical path length due to thermal expansion of the cells, (2) change of solute concentration due to thermal expansion of the solvent, (3) change of the degree of ionization of certain groups, (4) change of the intrinsic solvent effects, and (5) change of energy levels of electron of solute. Effect (1) will probably be negligible over usual temperature ranges. In effect (2) the concentration of $\alpha_{\mathrm{s}}$-casein is decreased by about $2 \%$ from $5^{\circ} \mathrm{C}$ to $70^{\circ} \mathrm{C}$, and this amount affects little changes of $\Delta \varepsilon_{290}$ because $\varepsilon_{290}$ of $\alpha_{\mathrm{s}}$-casein is 2,070. Effect (3) was hardly recognized in the spectra of lysozyme, because the $\Delta$ s values of the spectra became greater in proportion to temperature as well as those of acetyl tyrosine ethylester and acetyl tryptophan ethylester which have the ionizing groups masked by acetyl and ethyl residues. Effect (3) was not recognized in $a_{\mathrm{s}}$-casein either, for the similar shifts of spectra were obtained in various ionic strengths. Effect (4) is appreciable. Increasing the temperature of water decreases its refractive index slightly $\left(n_{\mathrm{D}}^{20}=1.333 ; n_{\mathrm{D}}^{100}=\right.$ $1.318)$ and its dielectric constant substantially $\left(D^{20}=80 ; D^{100}=48\right)$. The shift of spectra by the solvent effects follows the equation of McRae, ${ }^{19}$ and therefore, a change of refractive index and dielectric constant leads to the shift of spectra. By using model compounds in the same solvent as a sample solution, the conformational changes of $a_{\mathrm{s}}$-casein can be known by deducting this effect. Effect (5) is as follows: the temperature tends to lower the peak of spectra and to shallow the trough of spectra. ${ }^{20}$ Comparing with the spectra of model compounds, this effect can be deducted from those of sample. Thus, the heat-induced net change of conformation can be measured.

There are a few reports ${ }^{21,22)}$ about the heatinduced changes of conformation of casein by UV measurement, but they have no regard for thermal effects. Yoshida ${ }^{22)}$ reported that the UV difference spectra of whole-casein showed red shift by heating. It is assumed that the blue shift of spectra might have been overlooked since thermal effects were not considered in his work, and that he would take thermal effects for the red shift.

\section{Effects of ionic strength}

The UV difference spectra at elevated temperature against $5.5^{\circ} \mathrm{C}$ were measured in various ionic strengths, and the blue shift of $a_{\mathrm{s}}$-casein spectra was observed in all ionic strengths prepared. The blue shift is caused by exposing of chromophor residues out of molecule. Though the exposing of chromophor residues is caused by either the dissociation or the unfolding of a molecule, it can not be known by which reason the blue shift of $a_{s}$-casin will be caused. Since the extent of association of $a_{\mathrm{s}}$-casein alters by ionic strength, ${ }^{23)}$ the measurements of UV difference spectra in various ionic strengths would mean the measurements on the various 
extents of associated $a_{\mathrm{s}}$-casein. Furthermore, at ionic strength above $0.4 a_{\mathrm{s}}$-casein exhibited a red shift and the aggregate was formed by heating. Thus, in spite of the occurrence of association and finally aggregation of $a_{\mathrm{s}}$-casein by heating, the blue shift was observed above $30^{\circ} \mathrm{C}$. Therefore, the blue shift of $a_{\mathrm{s}}$-casein spectra was considered to be caused by the unfolding of $a_{\mathrm{s}}$-casin.

It is known that $a_{\mathrm{s}}$-casein associates one another with increasing in ionic strength and form the turbidity finally. ${ }^{24}$ It was found, however, that $a_{\mathrm{s}}$-casein became to form aggregate with increasing in temperature at the ionic strength of above 0.4 , and that the turbidity was not observed at ionic strength of zero to 0.2 even by the increasing in temperature. These phenomena are considered to be caused by that the conformation of $\alpha_{\mathrm{s}}$-casein is unfolded by heating and the hydrophobic regions are exposed. And the reason why the aggregate is not formed at low ionic strength $(0 \sim 0.2)$ may be the strong repulsion among charges of molecules. The formation of aggregate at ionic strength above 0.4 will occur by weakening the repulsion by enough counter ions in solvent. It can be also understood from above explanation that the higher in ionic strength, the lower in the temperature where the aggregation is formed.

\section{The aggregation process of $\alpha_{\mathrm{s}}$-casein by heating}

From these results, it is speculated that $a_{\mathrm{s}}$ casein is subjected to the following conformational changes by heating. The chromophor residues of $a_{\mathrm{s}}$-casein molecules which have been buried in the internal hold are exposed to the solvent above $30^{\circ} \mathrm{C}$, and by further heating $a_{\mathrm{s}}$-casein alters to the random structure. Accompanying with the alteration of the structure, the hydrophobic residues are exposed to the solvent and $a_{\mathrm{s}}$-casein associates and then aggregates by heating at the ionic strength where the aggregate is not formed at room temperature. These conformational changes and association of $a_{\mathrm{s}}$-casein are reversible until the aggregate is formed.
These process are shown by a diagram as follows:

Native $a_{\mathrm{s}}$-casein $\rightleftarrows$ Unfolded $a_{\mathrm{s}}$-casein

\section{(1) \\ Aggregated $a_{\mathrm{s}}$-casein}

(1) This process is reversible. $a_{\mathrm{s}}$-Casein is unfolded by heating. (2) This process is irreversible. Unfolded $a_{\mathrm{s}}$-casein is mutually aggregated.

The degrees of the association or aggregation of $a_{\mathrm{s}}$-casein under these conditions are not clear, and this is a problem to be investigated further.

Acknowledgement. We are greatly indebted to the members of the Division of Physical Chemistry, Institute for Protein Research, Osaka University, for helpful suggestions and discussions.

\section{REFERENCES}

1) K. Yamauchi, Jap. J. Sci,, 15, A-51 (1966).

2) W. H. Sawyer, J. Dairy Sci., 52, 1347 (1969).

3) Dyson Rose, Dairy Sci. Abs., 25, 45 (1963).

4) T. T. Herskovits, Biochemistry, 5, 1018 (1966).

5) G. C. Kresheck, Q. Van Winkle and I. A. Gould, J. Dairy Sci., 47, 117 (1964).

6) R. B. Leslie, L. Irons and D. Chapman, Biochim. Biophys. Acta, 188, 237 (1969).

7) C. A. Zittle and J. H. Custer, J. Dairy Sci., 46, 1183 (1963)

8) R. W. Noble Jr. and D. F. Waugh, J. Am. Chem. Soc., 87, 2236 (1965).

9) K. Imai, T. Takagi and T. Isemura, J, Biochem., 53, 1 (1963).

10) M. Sela, C. B. Anfinsen and W. F. Harrington, Biochim. Biophys. Acta, 26, 502 (1957).

11) C. H. W. Hirs, S. Moore and W. H. Stein, J. Biol. Chem., 219, 623 (1956).

12) H. E. Swaisgood, S. N. Timasheff, Arch. Biochem. Biophys., 125, 344 (1968).

13) T. Ono, K. Yutani and S. Odagiri, in preparation.

14) T. Ono and K. Yutani, unpublished.

15) D. B. Wetlaufer, Advance in Protein Chem., 17, 336 (1962).

16) J. G. Foss, Biochim. Biophys. Acta, 47, 569 (1961)

17) K. C. Aune, A. Salahuddin, M. H. Zariengo and C. Tanford, J. Biol. Chem., 242, 4486 (1967).

18) W. Kauzman and H. Eyring, J. Chem. Phys., 9, $41(1941)$

19) E. G. McRae, J. Phys. Chem., 58, 1002 (1954.)

20) "Ultraviolet and Visible Spectroscopy," by C. N. R. Rao, Butterworth and Co. Ltd., (1961). 
21) J. Garnier, J. Mol. Biol., 19, 586 (1969).

22) S. Yoshida, Nippon Nogeikagaku Kaishi, 43, 514 (1969).

23) D. G. Schmidt and B. W. Van Markwijk, Biochim.
Biophys. Acta, 154, 613 (1968).

24) D. F. Waugh, L. K. Creamer, C. W. Slattery and G. W. Dresdner, Biochemistry, 9, 786 (1970). 